\title{
Pengaruh Model Pembelajaran Contextual Teaching Learning (CTL) Terhadap Hasil Belajar IPS Siswa SD
}

\section{The Influence of Contextual Teaching Learning (CTL) Model on the Social Science Learning Outcomes of Elementary School Students}

\author{
Erawati Erni ${ }^{1}$, Muhammad Yunus ${ }^{2}$, Muhammad Nur² \\ 1Dinas Pendidikan Kota Makassar, Sulawesi Selatan \\ 2Program Studi Studi Pendidikan Dasar, Program Pascasarjana, Universitas Bosowa \\ E-mail: erawatipgsd17@gmail.com
}

Diterima: 14 Juli 2020/Disetujui 07 Desember 2020

\begin{abstract}
Abstrak. Penelitian ini adalah penelitian eksperimen murni (True Eksprimen). Contextual teaching learning (CTL) dapat menghubungkan kemampuan yang diharapkan apda suatu mata pelajaran dengan pekerjaan atau kehidupan sehari-hari. Peneliti membatasi masalah yaitu siswa merasa bosan ketika belajar, kurang berpartisipasi, dan rendahnya perhatian siswa ketika pelajaran IPS, sehingga hasil belajar yang didapat masih dibawah nilai KKM. Tujuan Penelitian penulisan ini adalah sebagai berikut: (1) memperoleh gambaran tentang penerapan model pembelajaran CTL dalam pembelajaran IPS (2) memperoleh gambaran tentang hasil belajar IPS siswa yang diajar menggunakan Model Pembelajaran CTL. (3) mengetahui pengaruh tentang hasil belajar IPS antara yang diajar dengan model Pembelajaran CTL. Temuan penelitian ini menunjukkan bahwa model pembelajaran CTL berpengaruh terhadap peningkatan nilai hasil belajar IPS siswa. Setelah dianalisis pengaruh tersebut disebabkan oleh: Pertama peserta didik kelas eksperimen proses pembelajaran lebih aktif dan bermakna daripada kelas kontrol. Kedua, penerapan model pembelajaran (CTL) dikelas tiga pada penelitian ini membuat peserta didik lebih aktif dalam proses pembelajaran. Ketiga salah satu prinsip pembelajaran CTL adalah konstruktivis. Esensi dari proses konstruktivis adalah bahwa peserta didik harus dapat menemukan dan mentrasformasikan suatu informasi ke situasi nyata. keempat adalah kegiatan diskusi yang dilaksanakan dikelas eksperimen. Kegiatan diskusi dalam pembelajaran CTL membangun terciptanya Learning Community, sehingga siswa yang memiliki kemampuan lebih akan membantu peserta didik lain yang kurang dalam kekompaknya.
\end{abstract}

Kata Kunci: Contextual Teaching Learning, Hasil Belajar, IPS

\begin{abstract}
This research is a pure experimental research (True Experiment). Contextual teaching learning (CTL) can connect the skills expected in a subject with work or daily life. Researchers limit the problem to students who feel bored when learning, lack of participation, and lack of student attention during social science lessons, so that the learning outcomes obtained are still below KKM score. The objectives of this research are as follows: (1) to obtain an overview of the application of CTL model in social science learning; (2) to obtain a description of the social science learning outcomes of students who are taught using CTL model; (3) to determine the effect of social science learning outcomes of those taught using CTL model. The findings of this study indicate that CTL model has an effect on increasing the students' social science learning outcomes. After analyzing the effect, it is caused by: First of all, in the experimental class, the learning process of students is more active and meaningful than the control class. Secondly, the implementation of CTL model in third grade in this study makes students more active during the learning process. Thirdly, one of the principles of CTL model is constructivism. The point of the constructivistic process is that students must be able to find and transform information into real situations. The fourth reason is a discussion activity carried out in the experimental class. Discussion activities in CTL model build the creation of community learning so that students who have more abilities will help other students who are less capable.
\end{abstract}

Keywords: Contextual Teaching Learning, Learning Outcomes, Social Science

\section{Pendahuluan}

Pendidikan memberikan kontribusi yang sangat besar terhadap kemajuan suatu bangsa dan sekaligus merupakan wahana dalam menerjemahkan pesan-pesan serta sarana dalam membangun watak bangsa. Sejalan dengan itu dalam bab I Permendikbud No. 22 tahun 2016 tentang standar proses Pendidikan dasar dan menengah ditegaskan bahwa "proses pembelajaran pada satuan pendidikan diselenggarakan secara interaktif, inspiratif, menyenangkan, menantang, memotivasi peserta didik untuk berpartisipasi aktif, serta memberikan ruang yang cukup bagi prakarsa, kreatif, dan kemandirian sesuai dengan bakat, minta dan perkembangan fisik serta psikologi peserta didik. Untuk itu setiap satuan pendidikan melakukan perencanaan pembelajaran, pelaksanaan proses pembelajaran serta penilaian proses pembelajaran untuk meningkatkan efesiensi dan efektifitas ketercapaian kompetensi lulusan". Proses pembelajaran yang dilakukan harus dapat memotivasi 
peserta didik untuk berpartisipasi aktif dalam pembelajaran. Hal tersebut hanya akan terjadi jika proses pembelajaran terlaksana dalam keadaan yang menyenangkan dan dapat mengispirasi serta memberi ruang yang cukup bagi peserta didik untuk mengembangkan minat dan bakatnya sesuai tingkat kemampuan dan potensinya.

Guru yang propesional harus berupaya melaksanakan proses pembelajaran dengan menerapkan berbagai model dan strategi pembelajaran. Model pembelajaran yang sesuai dengan karakterisitik mata pelajaran dan karakter peserta didik akan mampu mendorong tercapainya tujuan pembelajaran secara optimal. Masalah terbesar dalam dunia pendidikan saat ini adalah masalah lemahnya proses pembelajaran. Proses pembelajaran tidak mampu mendorong peserta didik untuk mengembangkan kemampuan berpikirnya. Guru melaksanakan pembelajaran hanya untuk memahamkan materi-materi yang ada pada setiap mata pelajaran untuk diketahui bukan diimplementasikan.

Salah satu mata pelajaran wajib pada tingkat Sekolah Dasar (SD) adalah Ilmu Pengetahuan Sosial (IPS). IPS memegang peranan yang sangat penting dalam usaha mengembangkan potensi peserta didik agar peka terhadap masalah sosial yang terjadi di masyarakat, memiliki sikap positip terhadap segala perubahan, perbaikan segala ketimpangan yang terjadi, dan terampil mengatasi setiap masalah yang terjadi sehari-hari pada dirinya dan masyarakat pada umumnya. IPS sebagai mata pelajaran pada tingkat SD dalam konteks ilmu sosial Nisbet (Sapriya: 2015:1) menyatakan bahwa ilmu sosial "All is change", dalam ilmu sosial tidak ada yang tetap, semua akan mengalami perubahan. Oleh karena itu dalam pengajaran perlu memperhatikan perubahan-perubahan yang terjadi dalam masyarakat.

Berdasarkan observasi yang kami lakukan diperoleh data hasil ujian tengah semester ganjil tahun ajaran 2018/2019 pada peserta didik kelas III SD Inpres Laikang termasuk rendah. Secara klasikal nilai rata-rata perolehan peserta didik adalah 62,07 dengan Kriteria Ketuntasan Minimal (KKM) 70,00 dari 81 peserta didik, sebanyak 35 peserta didik tuntas. Hasil belajar yang diperoleh peserta didik tersebut rendah, oleh karena konsep pembelajaran IPS yang sulit dipahami yang diingat peserta didik. Guru tidak menghubungkan materi keaplikasi dunia nyata atau pengalaman anak. Guru merancang pembelajaran pelaksanaannya hanya dalam ruang kelas. Peserta didik tidak difasilitasi untuk belajar dengan menggunakan lingkungan sekitar mereka sebagai tempat belajar. Padahal kajian materi ajar IPS sangat erat kaitannya dengan kegiatan atau peristiwa yang terjadi sehari-hari.

Model pembelajaran yang akan kami terapkan adalah model pembelajaran Contextual Teaching and Learning (CTL) atau biasa disingkat CTL dan membandingkannya dengan model konvensional yang umumnya dilakukan dengan guru. Melalui pembelajaran CTL maka masalah pembelajaran yang memposisikan peserta didik secara pasif (hanya mendengar) diharapkan dapat diatasi menjadi belajar peserta didik aktif sehingga hasil belajar peserta didik pada mata pelajaran IPS dapat meningkat. Dalam model pembelajaran ini, guru hanya memfasilitasi peserta didik untuk menemukan sendiri konsep pembelajaran melaui kegiatan menemukan sendiri dan menghubungkan materi pelajaran dengan kehidupan sehari-hari. Hal tersebut diharapkan akan membantu peserta didik dalam meningkatkan hasil belajar IPS.

Salah satu hal yang harus dikuasai oleh guru dalam mengajar adalah memahami teori-teori belajar dan prinsip-prinsip pembelajaran. Dalam modul B guru pembelajar kelas awal (Direktorat Jenderal Guru dan Tenaga kependidikan, 2016) pada kelompok kompetensi padaegogik dikemukakan beberapa pandangan tentang teori belajar.

1. Teori belajar dalam aliran Behaviorisme

2. Teori Belajar dalam aliran Kognitivisme

3. Teori Pemrosesan Informasi

4. Teori belajar dalam aliran konstruktivisme

5. Teori Belajar dalam aliran Humanisme

Kamus Besar Bahasa Indonesia Depdikbud (2008) mengartikan bahwa "hasil belajar adalah hasil pelajaran yang di peroleh dari kegiatan belajar di sekolah atau di perguruan tinggi yang bersifat kognitif dan biasanya ditentukan melalui pengukuran dan penilaian“. Syah Muhibbin (2003) mengemukakan bahwa "hasil belajar adalah hasil pengungkapan belajar yang meliputi ranah cipta (kognitif), ranah rasa (Afektif), dan ranah karya (Psikomotorik)".

Menurut Purwanto Ngalim (2004) bahwa hasil belajar biasanya dapat diketahui melalui kegiatan evaluasi yang bertujuan untuk mendapatkan data pembuktian yang akan menunjukkan sampai dimana tingkat kemampuan dan keberhasilan peserta didik dalam pencapaian tujuan pembelajaran, hasil belajar diukur dengan berbagai cara misalnya, proses bekerja hasil karya, penampilan, rekaman dan tes. Djamarah (2016) mengemukakan bahwa "hasil belajar adalah serangkaian kegiatan jiwa raga untuk memperoleh suatu perubahan tingkah laku sebagai hasil dari pengalaman individu dalam interaksi dengan lingkungan yang menyangkut kognitif, Afektif dan Psikomotorik".

Berdasarkan pendapat diatas dapat disimpulkan bahwa hasil belajar adalah kemampuan yang dimiliki peserta didik setelah ia menerima pengalaman belajarnya, dimana hasil belajar dapat dilihat dari hasil yang dicapai peserta didik, baik hasil belajar (nilai), peningkatan kemampuan berpikir dan memecahkan masalah perubahan tingkah laku atau kedewasaannya. Jadi proses belajar adalah kempuan-kemampuan yang dimiliki oleh peserta didik setelah ia menerima pengalaman belajarnya (Jainuddin, 2019).

Hasil belajar yang dicapai oleh peserta didik dipengaruhi dua faktor utama yakni faktor dari dalam diri peserta didik itu dan faktor dari luar peserta didik. Sudjana (Rahman Tammeng: 2012) mengemukakan faktor-faktor yang mempengaruhi hasil belajar yaitu:

1. Faktor Internal (dari dalam individu yang belajar). Faktor yang memengaruhi kegiatan belajar ini lebih ditekankan pada faktor dari dalam individu yang belajar. Adapun faktor yang memengaruhi kegiatan tersebut adalah faktor psikologis, antara lain yaitu: Motivasi, Perhatian, Pengamatan, Tanggapan dan lain sebagainya.

2. Faktor Eksternal (dari luar individu belajar), pencapaian individu belajar perlu diciptakan adanya sistem lingkungan belajar yang kondusif. Hal ini akan berkaitan dengan faktor dari luar peserta didik. Adapun faktor yang mempengaruhi adalah mendapatkan pengetahuan, penanaman konsep, keterampilan dan pembentukan sikap. 
Clark (2002) dalam Purwanto Ngalim (2004), bahwa hasil belajar peserta didik disekolah 70\% dipengaruhi oleh kemampuan peserta didik dan 30\% dipengaruhi oleh lingkungan. Oleh karena itu sangat penting menumbuhkan motivasi belajar peserta didik melalui penerapan model pembelajaran yang efektif dan menyenangkan.

Pada jenjang SD/MI, materi pelajaran IPS diorganisasikan dengan menganut pendekatan terpadu (integrated). Dalam Permendiknas (2006) dikemukakan bahwa substansi mata pelajaran IPS SD/MI adalah IPS terpadu, IPS mengkaji seperangkat peristiwa, fakta, konsep dan generalisasi yang berkaitan dengan isu sosial. Pada jenjang SD mata pelajaran memuat materi geografi, sejarah, sesiologi, dan ekonomi yang bertujuan untuk mendorong peserta didik untuk dapat menjadi warganegara Indonesia yang demokratis, dan bertanggung jawab, serta warga dunia yangcinta damai. Dalam modul 1, Bahan ajar pelatihan paska UKA bagi guru SD oleh BPSMDK dikemukakan kedudukan mata pelajaran IPS di sekolah dasar (SD) sejak dikeluarkannya UU no. 20 tahun 2003.

Pengembangan kurikulum IPS tidak lagi dilakukan oleh pemerintah pusat melainkan tanggung jawab setiap satuan Pendidikan. Ini sebuah keniscayaan. KTSP, terdiri 5 kelompok mata pelajaran yakni agama dan Akhlak Mulia, kewarganegaraan dan Kepribadian, Ilmu Pengetahuan dan Teknologi, Estetika; Pendidikan Jasmani, Olah Raga, dan Kesehatan (PP No.19 tahun 2005). Dalam PP tersebut (pasal 7 ayat 3; pasal 70 ayat 2 dan 4) ilmu pengetahuan sosial termasuk dalam kelompok mata pelajaran Ilmu Pengetahuan dan Teknologi. Pada kurikulum ini IPS dibelajarkan dengan pendekatan tematik pada kelas I sampai III dan pendekatan mata pelajaran pada Kelas IV sampai VI.

Arah mata pelajaran IPS dilatarbelakangi oleh kebutuhan masa yang akan datang dalam rangka menyiapkan peserta didik untuk menghadapi tantangan kehidupan masyarakat global yang penuh persaingan dan terus mengalami perubahan. Sapriya (2215) mengemukakan tentang tujuan pelajaran IPS SD sebagai berikut:

a. Mengenal konsep-konsep yang berhubungan dengan kejadian dan peristiwa yang terjadi dalam masyarakat dan lingkungannya.

b. Memiliki kemampuan dasar untuk berpikir kritis dan logis, memiliki rasa ingin tahu, inquiri dan mampu memecahkan masalah dan keterampilan dalam kehidupan masyarakat.

Secara rinci Suradisastra (1993) merumuskan tujuan pendidikan IPS sebagai berikut:

a. Pengetahuan dan Pemahaman

b. Sikap Belajar

c. Nilai-nilai Sosial dan

Joice dan Will dalam Rusman (2012) mengemukakan bahwa model pembelajaran adalah pola umum perilaku pembelajaran untuk mencapai tujuan pembelajaran akan dicapai. Model pembelajaran merupakan suatu rencana atau pola yang dapat digunakan untuk membentuk kurikulum (Rencana pembelajaran Jangka Panjang), merancang bahan-bahan pembelajaran, serta membimbing pembelajaran di kelas atau yang lain. Berdasarkan pengertian yang dikemukakan oleh J.R David tersebut terdapat dalam memilih model pembelajaran, hal pokok yang harus dipertimbangkan adalah kesesuaian antara model yang dipilih dengan kemungkinan efektifan model tersebut dalam mencapai tujuan. Ketercapaian tujuan tentu harus pula diukur dengan menggunakan instrumen evaluasi yang sesuai (Jainuddin \& Sirajuddin, 2020).

Secara spesifik, sebagaimana yang dituliskan oleh Sanjaya (2013) menjelaskan bahwa model pembelajaran adalah suatu kegiatan pembelajaran yang harus dikerjakan oleh guru dan peserta didik agar tujuan pembelajaran dapat dicapai secara efektif dan efesien. Berdasarkan pengertian diatas, dapat disimpulkan bahwa model pembelajaran adalah suatu rancangan kegiatan yang dilakukan oleh guru dan peserta didik dalam pembelajaran untuk mencapai tujuan.

a. Model Interaksi Sosial

Model pembelajaran sebagai interaksi sosial dikemukakan oleh Gestalt sebagaimana dikutip dalam (Rusman, 2013) yang mengatakan bahwa model interaksi sosial menitikberatkan hubungan yang humoris antara individu dengan masyarakat. Dalam model pembelajaran interaksi sosial mencakup strategi pembelajaran seperti kerja kelompok, pertemuan kelas, pemecahan masalah sosial, bermain peran, dan simulasi sosial. Dalam model pembelajaran interaksi sosial materi ajar diberikan secara utuh dan dilakukan dalam bentuk pembelajaran kelompok dan klasikal.

b. Model Pemrosesan Informasi

Model pembelajaran ini berdasarkan teori yang dikemukakan oleh Jean Piaget (Rusman 2013) yang beroriontasi pada kemampuan peserta didik dalam memproses informasi atau pengalaman baru yang dapat memperbaiki kemampuannya. Pemrosesan informasi merujuk pada cara mengumpulkan, menerima, stimulus dari lingkungan, mengoganisasikan data, memecahkan masalah, menemukan konsep, menggunakan simbol verbal dan visual.

c. Model Personal (Personal Models)

Model pembelajaran personal bertolak dari teori humanistik yang berorientasi terhadap pengembangan diri individu. Perhatian utamanya pada emosional peserta didik untuk mengembangkan hubungan yang produktif dengan lingkungannya.

d. Model Modifikasi Tingkah Laku

Rusman (2013) mengemukakan pengertian model pembelajaran modefikasi tingkah laku adalah model pembelajaran yang bertolak dari teori behavioristik, yaitu bertujuan untuk mengembangkan sistem yang efesian untuk mengurutkan tugastugas belajar dan membentuk tingkah laku dengan cara memanipulasi penguatan. Model ini lebih menekankan kepada perubahan tingkah laku.

Kumalasari (2014) mengemukakan pembelajaran Kontestual merupakan konsep dasar belajar dan mengajar yang membantu guru mengaitkan antara materi yang diajarkannya dengan situasi dunia nyata siswa dan mendorong siswa membuat hubungan antara pengetahuan yang dimilikinya dengan penerapannya dalam kehidupan mereka sebagai anggota keluarga, warga negara, dan pekerja. 
Rusman (2012) mengemukakan bahwa pembelajaran CTL merupakan konsep belajar yang dapat membantu guru mengaitkan materi ajar yang diajarkan kesituasi nyata. Strategi ini mendorong peserta didik untuk mampu menghubungkan pengetahuan yang dimilikinya, dengan mengaplikasinnya dalam kehidupan sehari-hari. Pembelajaran CTL bukan sekedar transformasi pengetahuan tetapi lebih kepada upaya memfasilitasi peserta didik untuk memperoleh kecakapan hidup dari apa yang telah dipelajarinya. Sejalan dengan hal tersebut Sugianto (Sudarminto, 2016) menyatakan bahwa pembelajaran CTL adalah suatu proses pendidikan yang bertujuan untuk mendorong peserta didik melihat makna didalam materi akademik yang mereka pelajari dengan cara menghubungkan subyek-subyek akademik dengan konteks kehidupan keseharian mereka.

Pengajaran dan Pembelajaran CTL merupakan suatu konsep yang membantu guru mengaikan konten mata pelajaran dengan situasi dunia nyata dan memotivasi peserta didik membuat hubungan antara pengetahuan dan penerapannya dalam kehidupan mereka sebagai anggota keluarga, warga negara, dan tenaga kerja US Departmen Of Education the National School-to-Work Office yang dikutip oleh Trianto (2008)Berdasarkan pengertian tersebut diatas, dapat dijelaskan konsep dasar model pembelajaran CTL yakni: (1) menekankan kepada proses keterlibatan peserta didik untuk menemukan materi, artinya proses belajar diorientasikan pada proses pengalaman secara langsung, (2) mendorong agar peserta didik menemukan hubungan antara materi yang dipelajari dengan situasi kehidupan nyata, dan (3) mendorong peserta didik untuk dapat menerapkannya dalam kehidupan nyata. Dari ketiga konsep yang disebutkan terlihat bahwa model pembelajaran CTL adalah sebuah model pembelajaran yang berorientasi penuh dalam melibatkan peserta didik, dimana dalam proses pembelajaran peserta didik didorong untuk menemukan materi, menghubungkannya dengan situasi kehidupan nyata dan mengamalkannya dalam kehidupan peserta didik sehari-hari. Pembelajaran CTL dapat pula dikatakan sebagai satu model pembelajaran yang tidak hanya beroriontasi pada hasil belajar tetapi pada proses belajar. Elaine B Johnson (2008: 187) mengemukakan bahwa dalam pembelajaran CTL adalah sebuah sistem yang merangsang otak untuk menyusun pola-pola yang mewujudkan makna, lebih lanjut Elaine mengatakan bahwa pembelajaran kontestual adalah semua sistem pembelajaran yang cocok dengan otak yang menghasilkan makna dengan menghubungkan muatan akademis dengan konteks dari kehidupan sehari-hari siswa.

Sanjaya (2013) mengemukakan lima karakteristik pembelajaran CTL sebagai berikut:

1. Pembelajaran merupakan proses pengaktifan pengetahuan yang sudah ada pengetahuan yang sudah dimiliki yang akan menjadi satu kesatuan yang utuh yang saling berkaitan.

2. Pembelajaran CTL adalah belajar dalam rangka menambah pengetahuan baru (Acquiring Knowledge), yang diperoleh secara deduktif.

3. Pemahaman, pengetahuan, (understanding knowledge), yang berarti bahwa pengetahuan yang didapat bukan untuk dihapal tetapi untuk dipahami dan dinyakini.

4. Mempraktekkan pengetahuan dan pengalaman (applying knowledge).

5. Melakukan reflesi (reflecting knowledge) terhadap strategi pengembangan pengetahuan.

Nurhayati (2011) mengemukakan bahwa pembelajaran CTL memiliki tujuh asas atau komponen yang harus tercermin dalam sebuah pembelajaran sebagai berikut:

1. Konstrutivisme (contructivisme) adalah landasan berpikir (filosofi) pendekatan kontekstual, yaitu dibangun oleh manusia sendiri sedikit demi sedikit, yang hasilnya diperluas melalui konteks yang terbatas.

2. Menemukan (Inquiry) artinya proses pembelajaran didasarkan pada pencarian dan penemuan melalui proses berpikir secara sistimatis. Bertanya (Quistioning)

3. Masyarakat Belajar (Learning Community), Menurut Leo Semonovich Vigostky, pengetahuan dan pemahaman anak ditopang banyak oleh komunikasi dengan orang lain. Konsep masyarakat belajar dalam pembelajaran CTL menyarankan agar hasil pembelajaran diperoleh melalui kerjasama dengan orang lain.

4. Pemodelan (Modeling) adalah proses pembelajaran dengan memperagakan sesuatu sebagai contoh yang dapat ditiru oleh setiap peserta didik.

5. Refleksi (reflection) adalah cara berpikir tentang apa yang baru terjadi atau baru saja dipelajari.

6. Penilaian Sebenarnya (Autentic Assesmen) adalah proses pengumpulan data dan informasi yang bisa memberikan gambaran dan petunjuk terhadap pengalaman belajar peserta didik.

Elaine B Johnson dalam Rustam (2009) menuliskan bahwa ada tujuh strategi yang harus dilalui dan dilaksanakan secara proporsional dalam pembelajaran CTL.

1. Pengajaran berbasis problem.

2. Menggunakan konteks yang beragam.

3. Mempertimbangkan ke-bhinekaan peserta didik.

4. Memberdayakan peserta didik untuk belajar sendiri.

5. Belajar melalui kolaborasi.

6. Menggunakan penilaian autentik.

7. Mengejar standar tinggi.

Penelitian bertujuan untuk (1) memperoleh gambaran tentang penerapan model pembelajaran CTL dalam pembelajaran IPS, (2) memperoleh gambaran tentang hasil belajar IPS siswa yang diajar menggunakan Model Pembelajaran CTL, (3) mengetahui pengaruh tentang hasil belajar IPS antara yang diajar dengan model Pembelajaran CTL.

\section{Metode Penelitian}

Jenis penelitian yang digunakan adalah Eksprimen murni (trus Eksprimen). Jenis eksprimen yang melakukan pretest sebelum adanya perlakuan. dua kelompok dipilih secara acak, diukur sebelum dan sesudah. Satu dari kelompok itu mendapatkan perlakuan, menurut Tiro (2014). Desain eksperimen yang digunakan dalam penelitian ini adalah non 
equivaterat control group desain. Rencangan ini tidak jauh berbeda pretest-postest kontrol group desain yang membedakan adalah dalam rancangan ini, baik kelompok eksperimen kelompok kontrol tidak dipilih secara randem (Asdar, 2018: 35) untuk memahami rancangan ini dapat dilihat gambar berikut:

Keterangan:

$$
\begin{array}{lll}
0_{1} & \times & 0_{2} \\
0_{3} & & 0_{4}
\end{array}
$$

$0_{1}$ dan $0_{3}=$ hasil tes awal sebelum diberi perlakuan

$\mathrm{O}_{2}$ dan $\mathrm{O}_{4}=$ hasil tes akhir setelah diberi perlakuan

$\mathrm{X}=$ perlakuan

Untuk mengetahui pengaruh perlakuan terhadap variabel terikat atau variabel dependen adalah $(02-01)-(04-03)$

Berdasarkan desain penelitian yang telah dipaparkan, peneliti melakukan dua kali tes pada masing-masing kelompok. Setelah kedua kelompok melakukan tes akhir, hasil keduanya kemudian dibandungkan atau diuji perbedaannya. Perbedaan yang signifikan antara kedua nilai dikelompok eksperimen dan kelompok kontrol akan menunjukkan pengaruh dari perlakuan yang diberikan. Variabel dalam Penelitian ini ada dua macam, variabel Independan (bebas) yaitu model pembelajaran CTL dan model pembelajaran konvensional. Variabel devenden (terikat) yaitu hasil belajar IPS peserta didik.

Penelitian ini dilaksanakan di SD Inpres Laikang di Jalan Goa Ria No. 31 Kecamatan Biringkanaya Kota Makassar. Untuk mendapatkan data yang akurat pada penelitian ini, peneliti menggunakan teknik-teknik yang tepat, yaitu teknik tes, teknik observasi dan instrumen penelitian

Pengumpulan data penelitian dilakukan dengan mempergunakan instrumen-instrumen sebagai berikut:

a. Rencana Pelaksanaan Pembelajaran (RPP)

b. Lembar Observasi Guru

c. Lembar Observasi Peserta Didik

d. Tes Hasil Belajar

Setelah semua data terkumpul data di analisis. Data numerik dianalisis menggunakan SPSS versi 25

\section{Hasil dan Pembahasan}

\section{Deskripsi Penerapan Model Pembelajaran CTL Kelas III-A SD Inpres Laikang Kota Makassar.}

Gambaran pelaksanaan pembelajaran dengan model pembelajaran contekstual teaching and learning (CTL) pada mata pelajaran IPS di SD Inpres Laikang, meliputi persiapan, pelaksanaan dan evaluasi. Persiapan yang dilakukan oleh peneliti adalah telaah kurikulum yang dilanjutkan dengan pembuatan RPP dengan model Pembelajaran CTL. Setelah itu melakukan pemilihan sampel kelas yang akan di terapkan model pembelajaran CTL, dimana peneliti memilih kelas III-A sebagai kelas eksperimen atau kelas yang akan diterapkan model pembelajaran CTL. Sebelum memberikan perlakuan maka dilakukan pretest terlebih dahulu.

Setelah selesai melakuka pre-test, maka proses pembelajaran mulai dilakukan dengan menerapkan model pembelajaran CTL. Kegiatan pembelajaran dilakukan sebanyak 4 pertemuan dengan materi pokok (jenis-jenis pekerjaan dan jual beli). Materi tersebut terbagi ke dalam 2 kompetensi dasar (KD) yang dibagi menjadi beberapa indikator yang diajarkan dalam tiaptiap pertemuan. Selanjutnya pada kegiatan inti, peserta didik dibagi kedalam 5 kelompok kecil yang beranggotakan 4-5 secara heterogen. Pada kesempatan ini peserta didik dapat bertanya langsung tentang hal-hal yang berkaitan dengan pekerjaan yang berkaitang dengan pendongeng. Kegiatan ini berlangsung selama 10 menit. Setelah sesi tanya jawab dengan narasumber, secara berkelompok peserta didik bekerja sesuai dengan LKS tentang pekerjaan orangtua mereka dan barang atau jasa yang dihasilkan. Perwakilan kelompok mempresentasikan hasil diskusi kelompoknya di depan teman-temannya dan kelompok lain memberikan tanggapan.

Sebagai kegiatan akhir, dengan berdasarkan hasil presentase seluruh kelompok, guru membimbing peserta didik menyimpulkan materi tentang jenis-jenis pekerjaan yang menghasilkan barang dan jasa dilanjutkan penilaian dan pemberian pengahargaan untuk partisipasi setiap kelompok dalam pembelajaran.

Kegiatan terakhir dalam pelaksanaan ini penelitian ini adalah evaluasi dari hasil proses pembelajaran menggunakan model CTL.

Pengaruh Model Pembelajaran Contextual Teaching and Learning (CTL) Terhadap Hasil Belajar IPS Siswa kelas III SD Inpres Laikang Kota Makassar

Pada sub bagian ini akan menjawab rumusan masalah yaitu apakah model pembelajaran Contextual Teaching and Learning $(C T L)$ berpengaruh terhadapt hasil belajar IPS Siswa SD Inpres Laikang. Analisis statitistik inferensial dalam menguji hipotesis, maka diperlukan pengujian dasar terlebih dahulu yaitu uji normalitas dan uji homogenitas.

Uji normalitas dilakukan untuk mengetahui apakah sebaran data berdistribusi normal atau tidak. Pada penelitian ini uji normalitas dengan menggunakan Kolmogrov-Smirnov. Kriteria yang digunakan, yaitu data dikatakan berdistribusi normal jika harga koefisien Asymptotic Sig pada output Kolmogorov-Smirnov tes lebih besar dari nilai alpha yang ditentukan, yaitu $5 \%(0,05)$. Setelah dilakukan perhitungan dengan bantuan program SPSS Versi 25 for windows di dapat hasil dibawah ini. 
Tabel 1 Hasil Uji Normalitas

\begin{tabular}{|c|c|c|c|}
\hline \multirow{2}{*}{\multicolumn{2}{|c|}{$\mathrm{N}$}} & Nilai Pretest & Nilai Posttest \\
\hline & & 40 & 40 \\
\hline \multirow{2}{*}{ Normal Parameters } & Mean & 61.8000 & 72.2500 \\
\hline & Std. Deviation & 6.36174 & 11.21526 \\
\hline \multirow{3}{*}{ Most Extreme Differences } & Absolute & .093 & .123 \\
\hline & Positive & .075 & .123 \\
\hline & Negative & -.093 & -.081 \\
\hline \multirow{2}{*}{\multicolumn{2}{|c|}{$\begin{array}{c}\text { Test Statistic } \\
\text { Asymp. Sig. (2-tailed) }\end{array}$}} & .093 & .123 \\
\hline & & $.200^{\mathrm{c}, \mathrm{d}}$ & $.128^{\mathrm{c}}$ \\
\hline \multicolumn{4}{|c|}{ a. Test distribution is Normal. } \\
\hline \multicolumn{4}{|c|}{ b. Calculated from data. } \\
\hline \multirow{2}{*}{\multicolumn{4}{|c|}{ c. Lilliefors Significance Correction. }} \\
\hline & & & \\
\hline
\end{tabular}

Berdasarkan Tabel 1 diperoleh informasi bahwa nilai Asymptotic Sig pada Kolmogorov-Smirnov pre-test kelas kontrol sebesar 0,200 dan post-test kelas kontrol sebesar 0.128 yang berarti lebih besar dari nilai alpha yang ditentukan yaitu 5\% $(0,05)$. Hal ini menunjukkan bahwa data pre-test dan post-test kelas kontrol berdistribusi Normal

Uji homogenitas dilakukan untuk memastikan kelompok data berasal dari populasi yang homogen atau tidak. Dalam penelitian ini uji homogenitas dengan menggunakan uji lavene tes dengan bantuan program SPSS versi 25. Kriteria yang digunakan, yaitu data dikatakan homogen jika harga koefisien Asymptotic Sig. pada output Lavene tes lebih besar dari nilai alpha yang ditentukan, yaitu 5\% $(0,05)$.

Tabel 2 Uji Homogenitas (Eksperimen-Kontrol)

\begin{tabular}{lcccc}
\hline & Levene Statistic & df1 & df2 & Sig. \\
\hline Based on Mean & 2.166 & 12 & 24 & .052 \\
Based on Median & 1.048 & 12 & 24 & .441 \\
Based on Median and with adjusted df & 1.048 & 12 & 11.963 & .469 \\
Based on trimmed mean & 2.074 & 12 & 24 & .062 \\
\hline Sumber: Analisa Data, 2020 & & &
\end{tabular}

Sumber: Analisa Data, 2020

Berdasarkan tabel 3.2 diketahui bahwa nilai Asymptotic Sig. pada levene tes variabel pre-test (eksperimen-kontrol) sebesar 0.052 yang berarti lebih besar dari nilai alpha yang ditentukan yaitu 5\% $(0,05)$ hal tersebut dapat disimpulkan bahwa data tersebut homogeny

Uji hipotesis dilakukan setelah data dari tesi hasil belajar terkumpul. Dalam penelitian ini, uji hipotesis menggunakan uji paired sample T-test dengan bantuan SPSS Versi 25 for windows. Uji paired sample T-test digunakan untuk mengetahui ada pengaruh yang signifikan atau tidak.

Tabel 3 Hasil Uji Hipotesis Paired Sample T-Test

\begin{tabular}{|c|c|c|c|c|c|c|c|c|c|}
\hline & & \multicolumn{5}{|c|}{ Paired Differences } & \multirow{3}{*}{$\mathrm{t}$} & \multirow{3}{*}{ df } & \multirow{3}{*}{$\begin{array}{l}\text { Sig. (2- } \\
\text { tailed) }\end{array}$} \\
\hline & & \multirow[t]{2}{*}{ Mean } & \multirow{2}{*}{ Std. Deviation } & \multirow{2}{*}{$\begin{array}{l}\text { Std. Error } \\
\text { Mean }\end{array}$} & \multicolumn{2}{|c|}{$\begin{array}{l}\text { 95\% Confidence Interval of the } \\
\text { Difference }\end{array}$} & & & \\
\hline & & & & & Lower & Upper & & & \\
\hline Pair 1 & $\begin{array}{l}\text { Nilai_Postest - } \\
\text { Nilai_Pretest }\end{array}$ & $\begin{array}{r}24.560 \\
98\end{array}$ & 10.85138 & 1.69470 & 21.13586 & 27.98609 & $\begin{array}{r}14.49 \\
3\end{array}$ & 40 & .000 \\
\hline
\end{tabular}

Sumber: Analisa Data, 2020

Berdasarkan tabel di atas diketahui bahwa nilai Asymptotic Sig sebesar 0,000 yang artinya kurang dari Sig alpha yang ditentukan yaitu $5 \%(0,05)$ maka ada pengaruh yang signifikan dengan penggunaan model pembelajaran Contextual Teaching and Learning (CTL)pada hasil belajar IPS siswa kelas III B SD Inpres Laikang. Meskipun dalam pembelajaran IPS dari kedua kelas mengalami peningkatan, tapi dilihat dari nilai rata-rata peningkatan kelas kontrol tidak signifikan dibandingkan dengan kelas eksperimen. Berikut ringksan nilai rata-rata dari kelas eksperimen dan kelas kontrol.

Temuan penelitian ini menunjukkan bahwa model pembelajaran CTL berpengaruh terhadap peningkatan nilai hasil belajar IPS peserta didik. Sertelah dianalisis pengaruh tersebut disebabkan oleh:

Pertama peserta didik kelas eksperimen proses pembelajaran lebih aktif dan bermakna daripada kelas kontrol. Pembelajaran menjadi bermakna sebab lingkungan dan kejadian disekitar dijadikan sebagai sumber belajar peserta didik mengamati, bertanya, mencoba, membuat kesimpulan dan mempresentasekan hasil kerja kelompok. Hal ini sesuai pendapat piaget (Trianto 2008) bahwa pengalaman fisik yang dimanipulasi lingkungan penting bagi terjadinya perkembangan psikologis interaksi sosial dengan teman sebaya, berdiskusi dan berargumentasi akan membantu memperjelas pemikiran yang ada akhirnya membuat pemikiran itu menjadi lebih logis.

Kedua, penerapan model pembelajaran (CTL) dikelas tiga pada penelitian ini membuat peserta didik lebih aktif dalam proses pembelajaran. Hal ini sesuai dengan pendapat trianto (2008) yang mengatakan bahwa penerapan pembelajaran CTL akan diciptakan ruang kelas yang didalamnya ada peserta didik akan menjadi peserta aktif bukan hanya sebagai pengamat yang fasif, dan bertanggung jawab terhadap belajarnya. Penerapan model pembelajaran ini membantu peserta didik untuk menghubungkan materi ajar dengan situasi nyata. Hal ini dapat memotivasi peserta didik untuk membentuk hubungan antara pengetahuan dan aflikasinya dalam kehidupan sehari-hari baik sebagai individu, anggota masyarakat dan warga negara.

Penyebab ketiga salah satu prinsip pembelajaran CTL adalah konstruktivis esensi dari proses konstruktivis adalah bahwa peserta didik harus dapat menemukan dan mentrasformasikan suatu informasi ke situasi nyata. Pada proses ini peserta 
didik membangun sendiri pengetahuan mereka melalui keterlibatan aktif dalam pembelajaran. Selain itu materi ajar dikemas dalam bentuk yang menarik dan mengambil contoh kejadian sehari-hari yang nyata disekitar peserta didik. Bahkan pengalaman peserta didik dijadikan sebagai dasar untuk memberikan materi yang dapat mereka bawa kedalam bentuk lain yang abstrak atau mereka kembangkan ke bentuk yang lebih rumit. Dalam pembelajaran, merekalah yag menemukan sendiri makna dan konsep dari materi ajar. Menghubungkan dengan kejadian sehari-hari yang pernah mereka alami atau jumpai membuat pelajaran menjadi bermakna sehingga akan diingat dalam jangka waktu yang lama.

Penyebab keempat adalah kegiatan diskusi yang dilaksanakan dikelas eksperimen. Kegiatan diskusi di kelas eksperimen. dalam pembelajaran CTL akan membangun terciptanya Learning komoniti, peserta didik yaang memiliki kemampuan yang lebih akan membantu peserta didik lain yang kurang dalam kekompaknya. Metode ini dikenal pula dengan istilah tutor sebanya. Kegiatan diskusi dikelas dapat melibatkan setiap peserta didik untuk berkomunikasi dan berpendapat serta bertanggung jawab pada semua hal yang telah diucapkannya, karena disertai bukti relevan (mencoba).

Keempat hal tersebut diatas, dapat terlihat pada hasil observasi kegiatan didik yang menimbulkan belajar keaktifan peserta didik berupa motivasi belajar, perhatian terhadap materi ajar, aktifitas pemecahan masalah dalam kerja kelompok, kemampuan presentasi, menyimpulkan dan menghubungkan materi ajar dengan ide - ide baru atau kejadian seahri-hari. Sedangkan hasil observasi keterlaksanaan model pembelajaran CTL dalam pembelajaran yang dimulai dari kegiatan awal, inti dan akhir. Dari kedua hasil observasi tersebut, dapat disimpulkan bahwa pembelajaran yang menerapkan model pembelajaran CTL sangat mengaktifkan peserta didik mulai dari mengingat pengalaman, peristiwa disekitar serta kegiatan menggali informasi dan menemukan konsep hingga pada kegiatan presentasi dan menyimpulkan rangkaian kegiatan tersebut berpusat pada peserta didik.guru hanya membimbing dan memfasilitasi peserta didik menemukan konsep dan bertanggung jawab terhadap belajarnya.

Proses pembelajaran yang menerapkan model pembelajaran CTL akan mampu menciptakan peserta didik yang terampil, kreatif dan mampu memecahkan masalah yang dihadapinya dalam kehidupan sehari-hari. Peningkatan kualitas proses pembelajaran akan mampu mengoptimalkan pencapaian tujuan pembelajaran yang akan mendorong terciptanya generasi masa depan yang aktif, kreatif, produktif, percaya diri, mandiri, saling menghargai serta berkeadilan dalam membangun dan mensejahterakan negara indonesia tercinta ini. peneliti juga nyakin bahwa jika model pembelajaran CTL diterapkan secara baik dan benar maka generasi kita yang akan datang bisa lebih kompoten dan mampu bersaing diera globalisasi dan informasi yang semakin tak terbendung.

Saat pembelajaran kelas eksperimen dan kelas kontrol diajar oleh guru yang sama. Sehingga perlakuan yang berbeda hanya pada model pembelajaran yaitu pada kelas eksperimen menggunakan model pembelajaran contextual teaching and learning dan kelas kontrol menggunakan model pemebelajaran konvensional. Tingginya peningkatan skor rata-rata pada kelas eksperimen dibanding dengan kelas kontrol bisa menjadi bukti bahwa penggunaan model pembelajaran contextual teaching and learning pada hasil belajar IPS lebih efektif dibandingkan dengan pembelajaran konveksional. Peningkatan hasil belajar IPS siswa dengan menggunakan model pembelajaran contextual teaching and learning menunjukkan bahwa siswa senang belajar menggunakan metode pembelajaran contextual teaching and learning. Model pembelajarn contextual teaching and learning dapat mempermudah siswa dalam memahami materi, sehingga pada tes terakhir siswa mudah mengerjakan soal.

Hasil Uji paired sample t-test menunjukkan bahwa hasil penelitian menunjukkan ada pengaruh yang signifikan penggunaan model pembelajaran contextual teaching and learning pada nilai hasil belajar IPS Siswa. Berdasarkan hasil pengamatan, observasi dan hasil tes hipotesis menggunakan SPSS Versi 25 for windows, dapat disimpulkan bahwa model pembelajaran contextual teacing and learning lebih efektif dan berpengaruh signifikan saat diterapkan dalam pembelajaran IPS di kelas III SD Inpres Laikan

\section{Kesimpulan dan Saran}

Hasil penelitian dapat disimpulkan bahwa penerapan model pembelajaran CTL dalam pembelajaran IPS dengan tujuh komponem pembelajaran kontekstual yakni konstruktivisme, inquiry, modeling,questioning, learneing comunity, reflection dan autentic assesment yang dilaksanakan mulai dari kegiatan awal, inti dan akhir dapat mendorong siswa berpartisipasi aktif dalam proses pembelajaran. Peserta didik dapat menghubungkan konsep materi ajar dengan realitas kehidupan sehari-hari sehingga menjadikan pembelajaran menjadi bermakna. Saran hasil penelitian bahwa guru hendaknya menggunakan Model Pembelajaran Conxtual teaching and learning (CTL) agar peserta didik semakin antusias dalam belajar dan hasil belajar semakin meningkat, yang tentunya ditunjang oleh sarana dan prasarana dari Pemerintah. Kepala sekolah hendaknya berperan sebagai motivator dalam menerapkan Model Pembelajaran CTL pada pembelajaran di sekolah terutama pada mata pelajaran IPS yang konten materinya sangat erat dengan lingkungan dan realitas kehidupan sehari-hari.

\section{Daftar Pustaka}

Arikunto, Suharsimi.2009. Prosedur Penelitian Suatu Pendekatan Praktik. Jakarta. Rineke Cipta.

Asdar, 2018. Metode Penelitian Pendidikan. Yogyakarta, Penerbit AQ.

Djamarah. Saiful, Bahri dan Zain. 2000. Strategi Belajar Mengajar. Rieneka Cipta. Jakarta

http//edukasi kompasian.com/peranan-guru dalam pembangunan pendidikan karakter-di-sekolah-dasar (diakses tanggal 19

Maret 2019). 
Jainuddin, J. (2019). Peningkatan hasil Belajar Matematika Melalui Latihan Menyelesaikan Soal Secara Sistematis Pada Siswa Kelas XI. IPA1 SMA Negeri 2 Sungguminasa. Klasikal: Journal Of Education, Language Teaching And Science, 1(3), 44-52.

Jainuddin, J., \& Sirajuddin, S. (2020). Pengaruh Minat dan Kedisiplinan Siswa dengan Gaya Kognitif Field Indefendent terhadap Hasil Belajar Matematika Siswa SMK Farmasi Yamasi Makassar. Delta-Pi: Jurnal Matematika dan Pendidikan Matematika, 9(2).

Johnson, Elaine B 2009. Contextual Teaching \& Learning: Menjadikan Kegiatan Belajar Mengajar Mengasyikkan dan Bermakna. Bandung MLC.

Komalasari Kokom. 2014. Pembelajaran Kontekstual Konsep dan Aplikasi. Bandung. Refika Aditama.

Muhibbin, S. (2003). Psikologi belajar. Jakarta: PT. Raja Grafindo Persada.

Nurhayati. 2011. Strategi Belajar Mengajar. Makassar. Badan penerbit Universitad Negeri Makassar.

Purwanto, Ngalim (2004). Psikologi pendidikan. Bandung: Remaja Rosdakarya.

Rusman. (2012). Seri Manajemen Sekolah Bermutu (Model-Model Pembelajaran: Mengembangkan Profesionalisme Guru). Jakarta Raja Grafindo Persada.

Sanjaya,Wina. 2013. Model Pembelajaran: Berorientasi Standar Proses Pendidikan. Jakarta. Kencana.

Sapriya 2015. Pendidikan IPS: Konsep dan Pembelajara Bandung. PT. Remaja Rosda Karya.

Sudarminta, J. 2013. Etika Umum: Kajian Tentang Beberapa Masalah Pokok Dan Teori Etika Normatif. Yogyakarta: Kanisius

Tammeng, Rahman. 2012. Meningkatkan Hasil Belajar IPS Melalui penerapan Model Pembelajaran Mind Mapping pada peserta didik kelas V SDN inpres 131 Tobonggae Kecamatan Camba Kabupaten Maros. Skripsi. Tidak diterbitkan. Makassar: FKIP Unismu Makassar.

Tiro, Muhammad Arif. Ahmar, Anshari, Saleh. 2014. Penelitian Eksperimen: merancang, Melaksakan, dan Melaporkan Makassar. Andira Publisher.

Trianto. 2008. Mendesain Pembelajaran CTL (Contextual Teaching and Learning (CTL)) Dikelas. Jakarta. Cerdas Pustaka. Undang-undang No. 20 Tahun 2003 tentang Sistem Pendidikan Nasional Sikdiknas Yaba. 2009. Materi Pendidikan IPS di SD. Makassar. Universitas Negeri Makassar. 